\title{
Hoffmeister Series Ions Protect Diphtheria Toxoid from Structural Damages at Solvent/Water Interface
}

\author{
Jocimara A.M. Namur ${ }^{1,3, \# \text {, Célia S Takata }}{ }^{2}$, Pedro S. de Araujo ${ }^{3}$ and \\ Maria H. Bueno-da-Costa ${ }^{1, *}$
}

1 Laboratório de Microesferas e Lipossomas - Centro de Biotecnologia- I. Butantan, Av. Vital Brasil, 1500, 05503-900 - Butantan, São Paulo, SP, Brazil

2 Divisão de Desenvolvimento Tecnológico e Produção-I. Butantan Av. Vital Brasil, 1500 (05503900) Butantan, São Paulo, SP, Brazil; E-Mail: celiatakata@butantan.br

3 I. de Química, (05508-000) Universidade de São Paulo Av. Lineu Prestes 748, São Paulo, SP, Brazil; E-Mails: joci_namur@yahoo.com.br (J.-A.-M.N.); psdarauj@usp.br (P.-S.-D.A.)

\# Present affiliation: Novartis, Brazil

* Author to whom correspondence should be addressed; E-Mail: bdacosta@usp.br; Tel. (5511) 3726 7222(Ext. 2265); Fax: (5511) 37261505

Received: 1 June 2009 / Accepted: 11 July 2009 / Published: 13 July 2009

\begin{abstract}
During the $\mathrm{W}_{1} / \mathrm{O}$ phase (in the $\mathrm{W}_{1} / \mathrm{O} / \mathrm{W}_{2}$ process) of protein microencapsulation within poly-lactide-co-glycolide (PLGA), hydrophobic interfaces are expanded where interfacial adsorption occurs followed by protein unfolding and aggregation. Spectroscopic and immunological techniques were used to ascertain the effects of the Hoffmeister series ions on Diphtheria toxoid (Dtxd) stability during the $\mathrm{W}_{1} / \mathrm{O}$ phase. A correlation was established between salts used in aqueous solutions and the changes in Dtxd solubility and conformation. The Dtxd $\alpha$-helical content was quite stable thus leading to the conclusion that encapsulation was followed by protein aggregation, with minor exposition of hydrophobic residues and a small change at the S-S dihedral angle. Dtxd aggregation is $95 \%$ avoided by the chaotropic $\mathrm{SCN}^{-}$. This was used to prepare a stable Dtxd and immunologically recognized/PLGA formulation in the presence of $30 \mathrm{mM} \mathrm{SNC}{ }^{-}$. The recovery increased by $10.42 \%$ or $23.2 \%$ when microencapsulation was within the COOMe or $-\mathrm{COOH}(12 \mathrm{kDa})$ PLGA, respectively. In conclusion, the aim of this work was achieved, which was to obtain the maximum of Dtxd stability after contact with $\mathrm{CH}_{2} \mathrm{Cl}_{2}$ to begin its PLGA microencapsulation within ideal conditions. This was a
\end{abstract}


technological breakthrough because a simple solution like salt addition avoided heterologous proteins usage.

Keywords: Hoffmeister series ions; protein solubilization; protein stabilization; interaction protein/organic solvent; protein microencapsulation; adjuvant particulate; adjuvant

\section{Introduction}

Protein encapsulation within poly-lactide-co-glycolide (PLGA) microspheres is a simple and straightforward procedure. To date, empirical approaches have been employed for protein stabilization during the first step of the double emulsion process $\left(\mathrm{W}_{1} / \mathrm{O} / \mathrm{W}_{2}\right)$.

In this step high pressures, temperature gradients and shear forces enhance the probability of oxidations to occur, leading to free radicals production and protein damages. When shear forces are considered, their net result is an increase in the organic solvent surface area which triggers protein adsorptions, aggregate precipitations and conformational damages [1-8]. BSA addition to diphtheria toxoid (Dtxd) or to tetanus toxoid (Ttxd) [9-10] was proposed to avoid antigen aggregation. The underlying supposition is that BSA competes with the antigen for the adsorption at the $\mathrm{CH}_{2} \mathrm{Cl}_{2} / \mathrm{H}_{2} \mathrm{O}$ interface. Evidently, this can occur. However, it is not reasonable to add heterologous proteins to pharmaceutical formulations intended for human usage. Another proposition was to increase the protein concentration, maintaining the same interfacial $\mathrm{CH}_{2} \mathrm{Cl}_{2} / \mathrm{H}_{2} \mathrm{O}$ area. Good results were obtained for carbonic anhydrase and BSA [11], lysozyme [12], and human growth hormone [13]. With insulin [14] the increase in concentration induces gel formation that leads to peptide stabilization. Other ideas were the co-dissolution of PLGA with non ionic surfactants [1,15-21] and protein chemical modifications with polyethylene glycol (PEG) [22]. It is known, from literature, that the Hoffmeister ions salts are able to change proteins solubilities (both, in water or at interface). Based on these facts it was decided to used them as a simple solution to avoid protein precipitations, aggregations or conformational modifications during the first phase (interfacial contact with $\mathrm{CH}_{2} \mathrm{Cl}_{2}$ ) of the W/O/W PLGA microsphere preparation. The salt can easily be removed after microsphere precipitation and washing. We discuss the mechanisms by which protein conformation is maintained and damages are avoided.

\section{Materials and Methods}

\subsection{Materials}

Dtxd and anti-diphtheric standard antiserum (developed in horses) were a gift from Instituto Butantan - Divisão de Produção. The immunoconjugates, Triton-X 114, poly-lactide-co-glycolide (PLGA 50:50, 45-75 kDa), dimethylsufoxide (DMSO) and 3,3',5,5'-tetramethylbenzidine (TMB) were from Polysciences; methylene chloride $\left(\mathrm{CH}_{2} \mathrm{Cl}_{2}\right)$, polyvinyl alcohol (PVA, MW 49,000) were from Merck and PLGAs (12kDa end terminal free or carboxymethylated) were from Boehringer Ingelheim. All the other reagents were of analytical grade. The following equipments were used: ultraconcentrator (Amicon); Cary 3E UV-Visible spectrophotometer (Varian), F 2000 spectrofluorimeter (Hitachi), 
spectropolarimeter Jobin Yvon (Spex CD6 Dichrograph Instrument); HPLC (Shimadzu) LC-10VP, equipped with UV detector (model SCL-10AVP); ELISA plate reader (Titerteck) Multiskan MCC/340, homogenizer (Ultra Turrax) T 25 basic IKA Labortechnik, RZR 2051 electronic evaporator (Heidolph) equipped with a tachometer.

\subsection{Effects of Hoffmeister series ions on the Dtxd solubility during emulsification with $\mathrm{CH}_{2} \mathrm{Cl}_{2}$}

Two $\mathrm{mL}$ samples of $5 \mathrm{mM}$ Dtxd in $\mathrm{KSCN}, \mathrm{MgCl}_{2}, \mathrm{NaCl}$ or $\mathrm{NaH}_{2} \mathrm{PO}_{4}(0,10,30,50,70,90,100$ and $150 \mathrm{mM}$ final concentrations) were added to $8 \mathrm{~mL} \mathrm{CH}_{2} \mathrm{Cl}_{2}$. After 2 minutes of emulsification at 24,000 rpm in the Ultra Turrax, samples were centrifuged during 15 minutes at $18,154 \mathrm{~g}$. The protein contents of the aqueous phases were measured by the absorbance at $269 \mathrm{~nm}$ (24) or by HPLC. The soluble fractions were analyzed by CD, fluorescence and ELISA.

\subsection{Circular dichroism}

The soluble Dtxd fractions in different salts at different concentrations were analyzed using a $0.1 \mathrm{~cm}$ path length cuvette in a Jobin Yvon spectropolarimeter.

\subsection{Fluorescence}

The soluble Dtxd fractions in different salts concentrations were analyzed using quartz cuvettes in a Hitachi F 2000 fluorimeter. The samples were excited at $269 \mathrm{~nm}$ and the fluorescence emission measured between 280 and $480 \mathrm{~nm}$.

\subsection{ELISA}

Dtxd soluble samples were added to ELISA plates and after two hours at $37^{\circ} \mathrm{C}$, they were blocked with $10 \%$ skim milk. After $30 \mathrm{~min}$, the standard anti-Dtxd specific sera, developed in horses, was added to the wells. The conjugate (anti-horse whole IgG conjugate with peroxidase) was added $30 \mathrm{~min}$ later, and, after a further $30 \mathrm{~min}$, the substrate was added. After $15 \mathrm{~min}$ at room temperature, the reaction was stopped with $1 \mathrm{M} \mathrm{H}_{2} \mathrm{SO}_{4}$. The absorbance was automatically measured at $450 \mathrm{~nm}$ in a Titertek Multiskan MCC/340. Antibody titters are the reciprocal serum dilution factor giving an absorbance value of $20 \%$ of the saturation value.

\subsection{Dtxd encapsulation within PLGA in the presence of KSCN}

The PLGA particles were prepared using the water in oil/in water $\left[\left(\mathrm{W}_{1} / \mathrm{O}\right) / \mathrm{W}_{2}\right]$ double emulsification solvent evaporation method. Briefly, under strong agitation, $125 \mu \mathrm{L}$ of PBS containing $30 \mathrm{mM} \mathrm{KSCN}$ were added to $200 \mathrm{mg}$ of PLGA (12 kDa, end terminal free or carboxymethylated) previously dissolved in $2 \mathrm{~mL}$ of $\mathrm{CH}_{2} \mathrm{CL}_{2}$. This mixture was then emulsified at 24,000 rpm for $2 \mathrm{~min}$ in an Ultra Turrax emulsifier. The emulsion was quickly added to $40 \mathrm{~mL}$ of $0.5 \%$ PVA and submitted to emulsification at 19,000 rpm for $2 \mathrm{~min}$. The solvent was evaporated by gentle stirring for 3 hours at $1,000 \mathrm{rpm}$ in a Heidolph ${ }^{\circledR}$ RZR 2051 helix evaporator. The microspheres were collected by centrifugation for $10 \mathrm{~min}$. at 2,000 g, rinsed with water three times and then resuspended with $2 \mathrm{~mL}$ of 
$0.1 \%$ PVA, freeze-dried for 24 hours and stored at $-20{ }^{\circ} \mathrm{C}$. The encapsulation efficiency was calculated measuring non-encapsulated protein in the supernatant.

\section{Results}

The Dtxd solubility was enormously affected by the emulsification both in the presence of $\mathrm{CH}_{2} \mathrm{Cl}_{2}$ and in the absence of salts (Figure 1), when 33\% of the molecule precipitated. The kosmotropics $\mathrm{NaH}_{2} \mathrm{PO}_{4}$ and $\mathrm{NaCl}$, practically did not alter protein recovery in all concentrations studied. It was interesting to note that the chaotropic $\mathrm{MgCl}_{2}$ precipitated at least $80 \%$ of Dtxd in all concentrations used. In contrast, the other chaotropic, KSCN solubilized Dtxd and 95\% of the protein was recovered after emulsification in the presence of the organic solvent (Figure 1, 30-70 mM KSCN).

Figure 1. Effects of Hoffmeister series ions on Dtxd recovery during emulsification with $\mathrm{CH}_{2} \mathrm{Cl}_{2}$. The kosmotropics $\mathrm{NaHPO}_{4}(\mathrm{o}), \mathrm{NaCl}(\Delta)$ or the chaotropics $\mathrm{KSNC}(\boldsymbol{\square})$ and $\mathrm{MgCl}_{2}$ $(\boldsymbol{\nabla})$ were added to the Dtxd water solutions and emulsified in the presence of $\mathrm{CH}_{2} \mathrm{Cl}_{2}$ at $24000 \mathrm{rpm}$. The soluble protein was measured by HPLC.

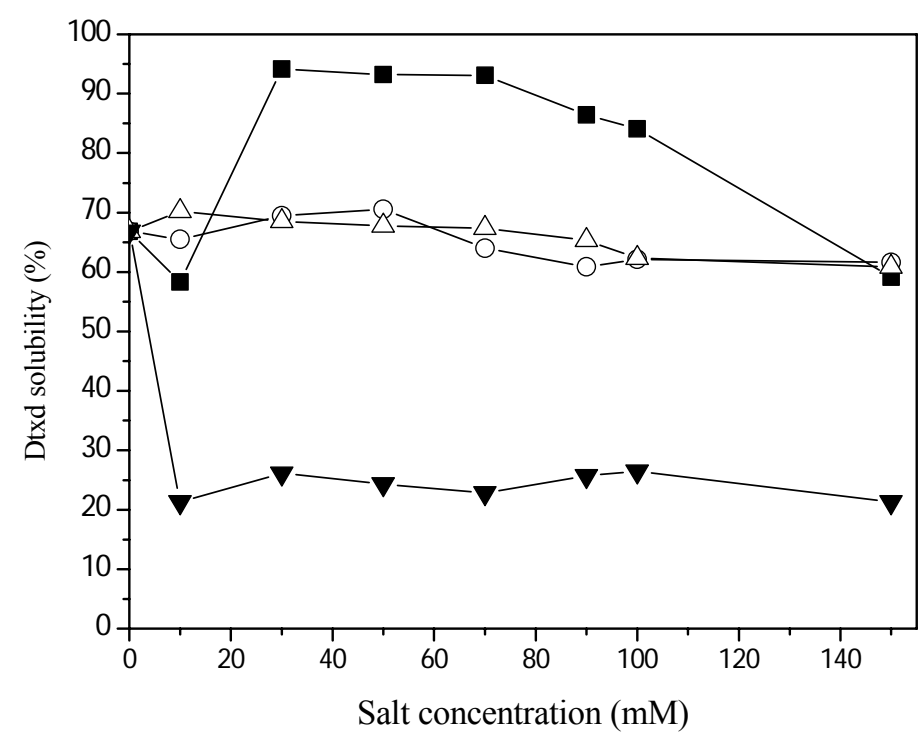

In order to know the nature and extent of these Dtxd losses, the soluble Dtxd fractions after emulsification in the presence of salts were applied on a gel filtration HPLC column (Figure 2). The dimer (2 x Dtxd) concentration was practically the same in all salt concentrations used (Figure 2A). There is a large reduction in Dtxd monomers when the emulsification was done in the presence of $\mathrm{MgCl}_{2}$ (Figure 2B). The increase in FA and FB (Fragments $\mathrm{A}$ and $\mathrm{B}$ ) occurred in concert with the decrease of Dtxd monomers when Dtxd was emulsified in the presence of $\mathrm{SCN}^{-}$, suggesting a significant Dtxd monomer hydrolysis. The decrease in monomers in the presence of $\mathrm{Mg}^{2+}$ and $\mathrm{PO}_{4}{ }^{2-}$ (Figure 2B) did not coincide with the dimer, FA or FB increases (Figure 2A). Probably, in these situations insoluble aggregates (containing more than 2 Dtxd monomers) could be formed, since the Dtxd dimer was still soluble (Figure 2A). 
Figure 2. Effect of Hoffmeister series ions in different Dtxd molecular species after emulsification in the presence of $\mathrm{CH}_{2} \mathrm{Cl}_{2}$. The kosmotropics $\mathrm{NaHPO}_{4}(\mathrm{o})$ and $\mathrm{NaCl}(\Delta)$ or the chaotropics $\mathrm{KSNC}(\boldsymbol{\nabla})$ and $\mathrm{MgCl}_{2}(\boldsymbol{\nabla})$ were added to the Dtxd water solutions and emulsified in the presence of $\mathrm{CH}_{2} \mathrm{Cl}_{2}$ at $24,000 \mathrm{rpm}$. A. Dtxd dimmer, B. Dtxd monomer and C. Fragments A and B. Controls: Dtxd emulsified without salt and methylene chloride (arrows in the pictures). The soluble Dtxd molecular species fractions were analyzed by HPLC gel filtration (QC-PACK GFC 300 column - $7.8 \mathrm{~mm} \mathrm{X} 15 \mathrm{~cm}$ ) previously equilibrated with PBS, at $20{ }^{\circ} \mathrm{C}$. Injection and elution flows were $0.6 \mathrm{~mL} / \mathrm{min}$.

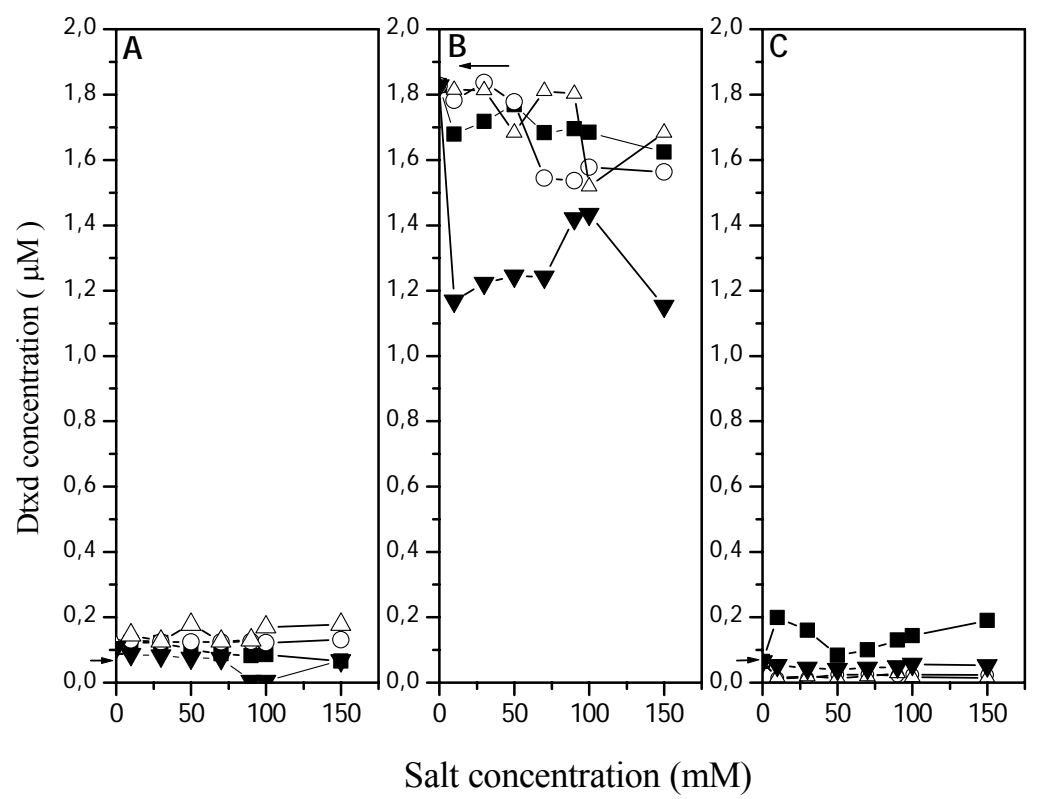

The lesser immunological identity of these fractions was observed when the emulsification was done in the presence of $\mathrm{MgCl}_{2}$ (Figure 3). The other salts, practically, did not alter the immunological identity of the soluble Dtxd fractions (Figure 3).

Figure 3. Immunological identity of the soluble Dtxd fractions. The kosmotropics $\mathrm{NaHPO}_{4}(\mathrm{o})$ and $\mathrm{NaCl}(\Delta)$ or the chaotropics $\mathrm{KSNC}(\boldsymbol{\nabla})$ and $\mathrm{MgCl}_{2}(\boldsymbol{\nabla})$ were added to the Dtxd solution in water and emulsified in the presence of $\mathrm{CH}_{2} \mathrm{Cl}_{2}$ at $24,000 \mathrm{rpm}$. The soluble fractions were analyzed by ELISA. Control: untreated protein with an absorbance of 0.52 absorbance units.

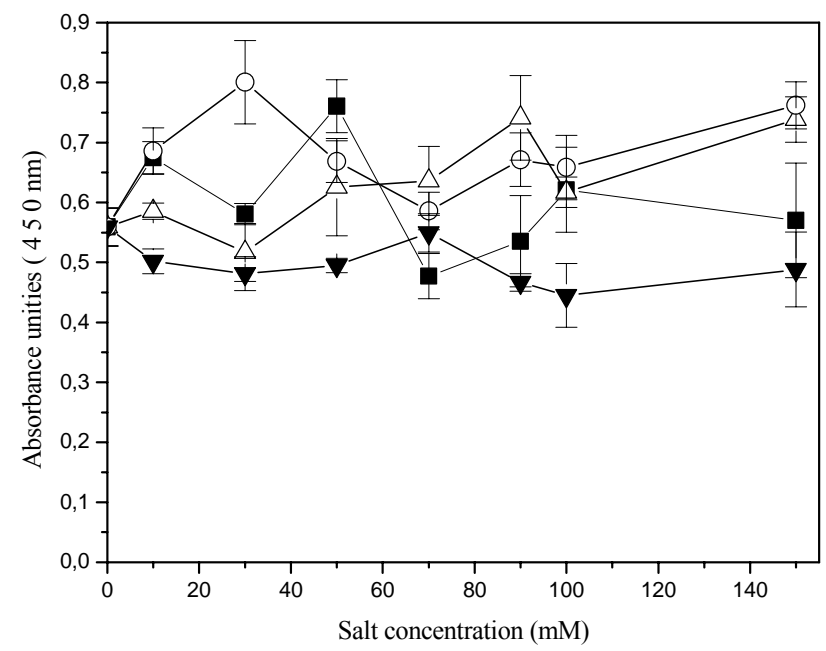


The extent of these conformational damages was analyzed by circular dichroism (Figure 4). Changes in the $\alpha$-helical content were observed at $\theta_{222 \mathrm{~nm}}$ (Figure 4) and for S-S dihedral angle conformations, at $\theta_{260 \mathrm{~nm}}$ (Figure 5). The $\alpha$-helical content in the presence of $\mathrm{NaH}_{2} \mathrm{PO}_{4}$ increased in all the concentrations studied (Figure 4). Oscillations on $\theta_{222 \mathrm{~nm}}$ in the lower $\mathrm{NaCl}$ concentration were observed. The biggest negative Cotton effect was observed in the Dtxd emulsified in the presence of $\mathrm{MgCl}_{2}$. In the presence of KSCN the Dtxd $\alpha$-helical content remained stable (Figure 4).

Figure 4. Effect of Hoffmeister series ions concentrations on $\theta_{222 \mathrm{~nm}}$ Dtxd. Soluble samples of $7.36 \mathrm{mM}$ Dtxd were obtained after emulsification in the presence of $\mathrm{CH}_{2} \mathrm{Cl}_{2}$ and the kosmotropics $\mathrm{NaHPO}_{4}(\mathrm{o})$ and $\mathrm{NaCl}(\Delta)$ or the chaotropics $\mathrm{KSNC}(\boldsymbol{\nabla})$ and $\mathrm{MgCl}_{2}(\boldsymbol{\nabla})$ and analyzed by $\mathrm{CD}$ spectroscopy.

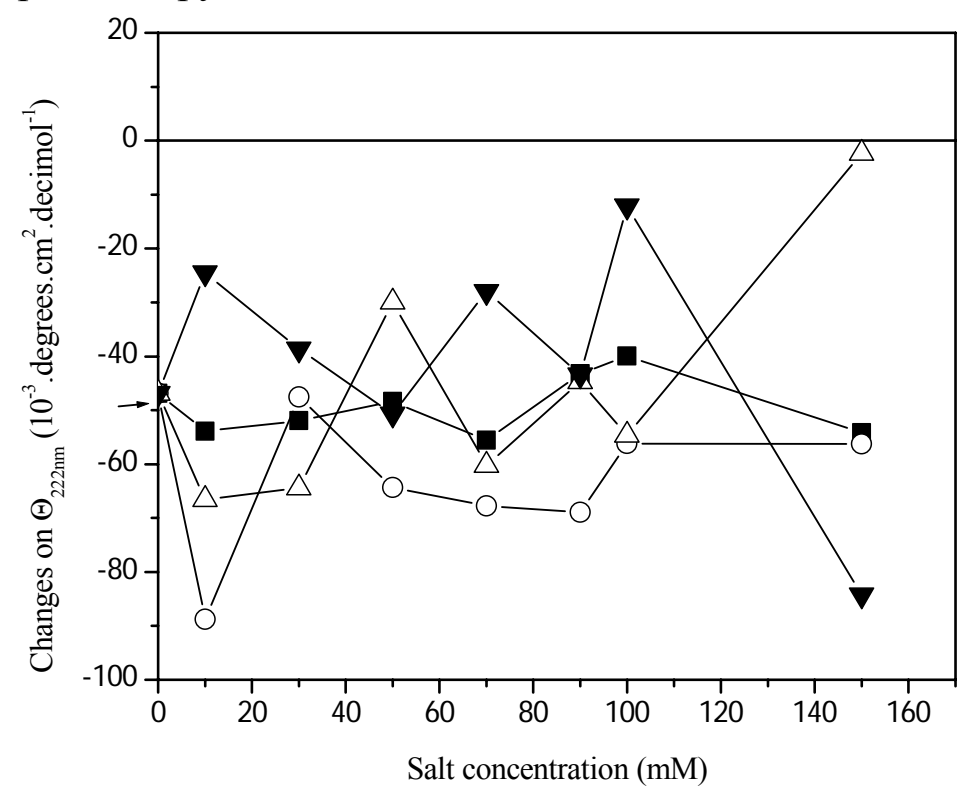

Figure 5. Effect of Hoffmeister series ions concentrations on $\theta_{260 \mathrm{~nm}}$ Dtxd. Soluble samples of $7.36 \mathrm{mM}$ Dtxd were obtained after emulsification in the presence of $\mathrm{CH}_{2} \mathrm{Cl}_{2}$ and the kosmotropics $\mathrm{NaHPO}_{4}(\mathrm{o})$ and $\mathrm{NaCl}(\Delta)$ or the chaotropics $\mathrm{KSNC}(\boldsymbol{\square})$ and $\mathrm{MgCl}_{2}(\boldsymbol{\nabla})$ and $\mathrm{CD}$ spectra were recorded (cuvettes of $0.1 \mathrm{~cm}$ path length).

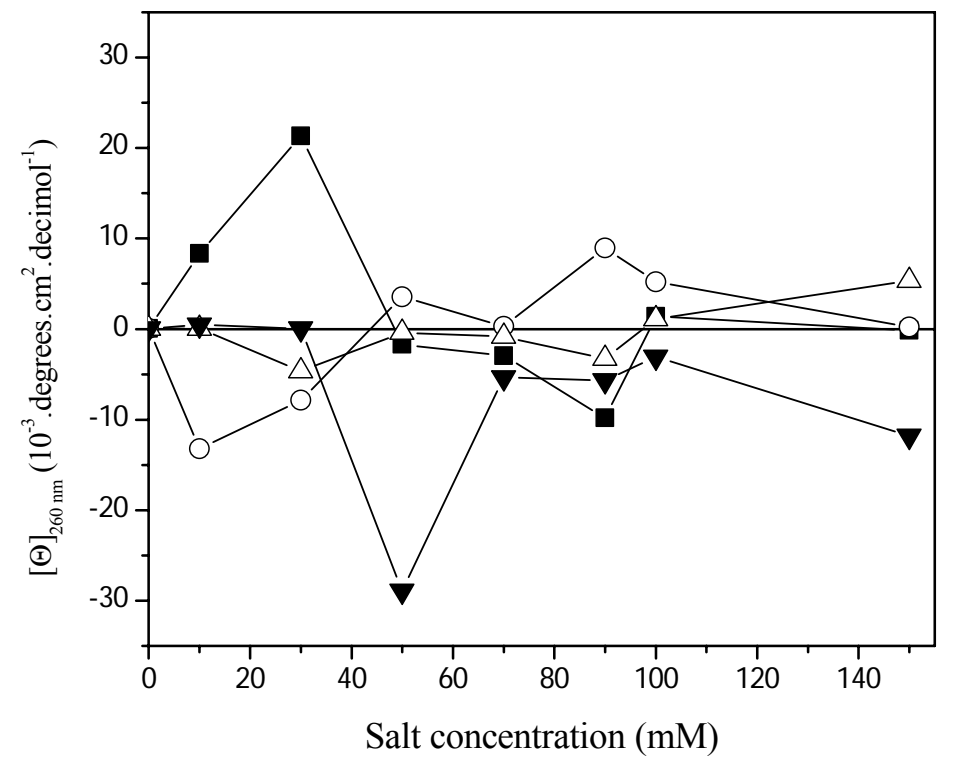


To facilitate the discussion, a schematic representation of Dtxd is shown in Scheme 1. It is important to note that diphtheria toxin has two $\mathrm{S}-\mathrm{S}$ bridges $\left(\mathrm{C}_{186}-\mathrm{C}_{201}\right.$ and $\left.\mathrm{C}_{461}-\mathrm{C}_{471}\right)$. One of them is an inter-peptide linkage (FA-FB, $\mathrm{C}_{186}-\mathrm{C}_{201}$ ) and the other is an intra-peptide linkage $\left(\mathrm{FB}, \mathrm{C}_{461}-\mathrm{C}_{471}\right)$. The dihedral S-S angle (linkage between the FA and FB) suffered conformational alterations during the simulation of the first emulsification during the microsphere preparation method (Figure 5). Probably, the observed dihedral changes are related with the $\mathrm{C}_{186}-\mathrm{C}_{201}$ bridge because of the steric hindrance and constraints on the other S-S linkage $\left(\mathrm{C}_{461}-\mathrm{C}_{471}\right)$. It is known that angular dihedral variations $\geq 120^{\circ}$ are related with a negative Cotton effect. In contrast, angular dihedral variations $\leq 60^{\circ}$ induce positive Cotton effects $[25,26]$.

Scheme 1. Representation of Dtxd (adapted from [23]).

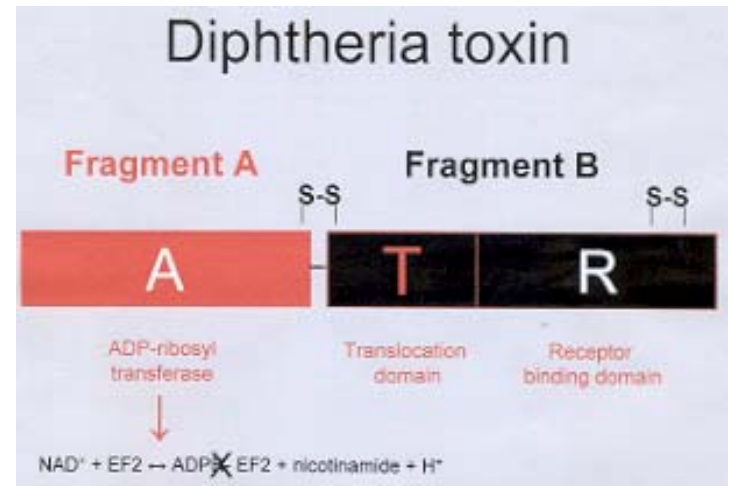

The lowest S-S dihedral conformational change was observed when Dtxd was emulsified in the presence of $\mathrm{NaCl}$ (Figure 5). From 10-40 $\mathrm{mM} \mathrm{NaH}_{2} \mathrm{PO}_{4}$ the S-S dihedral change was $\geq 120^{\circ}$ and above $50 \mathrm{mM} \mathrm{NaH}{ }_{2} \mathrm{PO}_{4}$ remained $\leq 60^{\circ}$. The biggest Dtxd S-S variations were observed in the presence of $\mathrm{MgCl}_{2}$. In the presence of $\mathrm{MgCl}_{2}$, the Dtxd opened its structure (the $\mathrm{S}-\mathrm{S}$ changed from $\leq 60^{\circ}$, a positive Cotton effect, to $\geq 120^{\circ}$ a negative Cotton effect). Between 50 and $70 \mathrm{mM} \mathrm{KSCN}$, the S-S dihedral Dtxd angle also changed its conformation, but the variations were close to zero and corresponded to a closed conformation.

It was observed in the fluorescence spectra that all $\mathrm{MgCl}_{2}$ concentrations studied produced the highest increase in the $\mathrm{F} 350 \mathrm{~nm} / \mathrm{F} 330 \mathrm{~nm}$ ratio (that corresponds to the degree of tryptophan, $\mathrm{W}$, exposition to the media). The $\mathrm{NaCl}$ and the $\mathrm{NaH}_{2} \mathrm{PO}_{4}$ induced an intermediate $\mathrm{W}$ exposition. The lowest W exposition was observed in the presence of KSCN (Figure 6).

Taking all the previous results into consideration, Dtxd microencapsulations within MS-PLGA in the presence of KSCN were performed and under this condition, the encapsulation efficiency raised from $53.84 \%$ to 64.26 (when the microencapsulation of Dtxd was done within the end methylated PLGA of $12 \mathrm{kDa}$ ) and $23.2 \%$ (from $46.41 \%$ to $69.63 \%$ ) within the free-COOH PLGA (12 kDa).

\section{Discussion}

It was verified in this work that simple molecules like Hoffmeister salts could be the best solution to protect the Dtxd protein from aggregation and conformational damages during the emulsification with $\mathrm{CH}_{2} \mathrm{Cl}_{2}$. Salts are easier to remove than exogenous proteins. The problem we faced was solved 
because high quantities of Dtxd were solubilized by $\mathrm{SCN}^{-}$and consequently increased the encapsulation efficiency.

Figure 6. Effect of Hoffmeister series ions on Dtxd intrinsic fluorescence. Soluble samples of $7.36 \mathrm{mM}$ Dtxd were obtained after its emulsification in the presence of $\mathrm{CH}_{2} \mathrm{Cl}_{2}$ and the kosmotropics $\mathrm{NaHPO}_{4}(\mathrm{o})$ and $\mathrm{NaCl}(\Delta)$ or the chaotropics $\mathrm{KSNC}(\boldsymbol{\square})$ and $\mathrm{MgCl}_{2}(\boldsymbol{\nabla})$ and the fluorescence spectra were recorded.

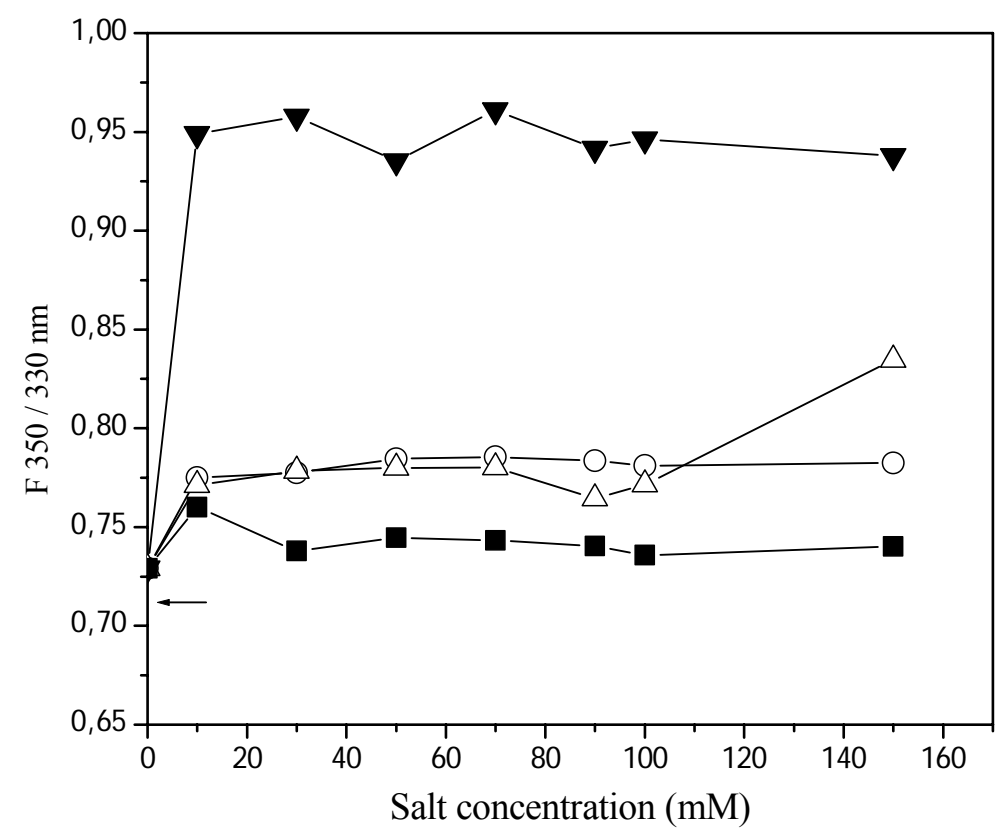

The enhancement of Dtxd protein solubility in the presence of $\mathrm{SCN}^{-}$contrasted with other literature results, where lisozyme was precipitated in the presence of this chaotropic [26]. When the solvent is changed (ethyl acetate, for example) the $\mathrm{SCN}^{-}$decreased Dtxd solubility [27], meaning that the protein partition depends on several factors like dielectric constant.

The problem approached in this work was not simple neither trivial: a ternary system composed by the protein Dtxd, the water and the organic solvent where a fourth element would be added - the salt, under a 24,000 rpm agitation! It would be an oversimplification to opt for one of the theories [28-31] to explain the Hoffmeister effect on protein solubility. The protein solubility change [30,31] in the presence of kosmotropic salts which stabilize solutes, by increasing the order of water or in the presence of chaotropic salts which create weaker hydrogen bonding thus decreasing the order of water and increasing its surface tension. Nowadays it is known that the Hoffmeister series mechanism of action is related to ion specific phenomena [29]. But, changes on water structure after salt additions do not explain the ion specific phenomenon [28,32]. Here the chaotropics $\mathrm{SCN}^{-}$and $\mathrm{Mg}^{2+}$ were used. In addition to their charge difference it is known that $\mathrm{SCN}^{-}$is poorly hydrated and $\mathrm{Mg}^{2+}$ is strongly hydrated [28,32]. The Dtxd was in water, $\mathrm{pH} 6.5$, and containing salt in a condition of $2 \mathrm{pH}$ units above its pI [23] with a net negative charge. Therefore, it is reasonable to assume that an ionic interaction between Dtxd (negatively charged) and $\mathrm{Mg}^{2+}$ did not favor protein solubility. In this salt condition the protein could precipitate after organic solvent contact, maximized by the agitation at $24000 \mathrm{rpm}$. So, here, the Hoffmeister series would be understood as an ion specific phenomenon 
[28,33]. The kosmotropic salts, $\mathrm{NaCl}$ and $\mathrm{NaH}_{2} \mathrm{PO}_{4}$ did not alter the Dtxd aggregation caused by agitation. The aggregation caused by the presence of $\mathrm{CH}_{2} \mathrm{Cl}_{2}$ was not associated to the increase in Dtxd dimmer (the dimmer is soluble) but with the formation of large aggregates. Dtxd was not hydrolyzed in FA and FB. The Dtxd soluble fraction immunologically recognized was lost after emulsification in the presence of $\mathrm{MgCl}_{2}$. This Dtxd not immunologically recognized conformation corresponded to a protein more folded and more exposed to the environment. This exposed protein showed its hydrophobic residues to the media. This fact corroborates the expressed hypothesis that $\mathrm{Mg}^{2+}$ interacted strongly with Dtxd. The $\mathrm{SNC}^{-}$protected Dtxd from unfolding, S-S dihedral opening and immunological damages. The Dtxd solubility increased $95 \%$ in the presence of $\mathrm{SNC}^{-}$, corresponding to a molecule in its native conformation. This technological gain was used to prepare a Dtxd/PLGA formulation in the presence of $30 \mathrm{mM} \mathrm{SNC}^{-}$. The recovery increased in $10.42 \%$ (from $53.84 \%$ to $64.26 \%$ ) the microencapsulation of Dtxd within the end methylated PLGA (12 kDa) and 23.2\% (from $46.41 \%$ to $69.63 \%)$ within the free-COOH PLGA (12 kDa).

\section{Conclusions}

In conclusion, the aim of this work was achieved, which was to obtain the maximum protein solubility after emulsification in the presence of $\mathrm{CH}_{2} \mathrm{Cl}_{2}$ to begin its PLGA microencapsulation within ideal conditions. This was a technological breakthrough because a simple solution such as salt addition avoided the usage of heterologous protein.

\section{Aknowledgements}

FAPESP (00/10970-7), CNPq (300648/2005-7 and 474781/01-1) and Fundação Butantan. JAM Namur had a fellowship from CNPq.

\section{References}

1. Wei, G.; Lu, L.F.; Lu, W.Y. Stabilization of recombinant human grow hormone against emulsification-induced aggregation by Pluronic surfactants during microencapsulation. Int. J. Pharm. 2007, 338, 125-132.

2. Pérez-Rodriguez, C.; Montano, N.; Gonzalez, K. Griebenow, Stabilization of chymotrypsin at the $\mathrm{CH}_{2} \mathrm{Cl}_{2}$ /water interface and upon water-oil-in-water encapsulation in PLGA microspheres. $J$. Control. Rel. 2003, 89, 71-85.

3. Castellanos, I.J.; Cruz, G.; Crespo, R.C.; Griebenow, K. Encapsulation-induced aggregation and loss in activity of $\gamma$-chymotryppsin and their prevention. J. Control. Release 2002, 81, 307-319.

4. Pérez, C.; Castellanos, I.; Costantino, H.; Al-Azzam, W.; Griebenow, K. Recent trends in stabilizing protein structure upon encapsulation and release from bioerodible polymers. J. Phar. Pharmacol. 2002, 54, 301-313.

5. Diwan, M.; Park, T.G. Pegylation enhances protein stability during encapsulation in PLGA microspheres. J. Control. Release 2001, 73, 233-244. 
6. Weert, M.; Hoechstetter, J.; Hennink, W.E.; Crommelin, D.J.A. The effect of water/organic solvent interface on the structural stability of lysozyme. J. Control. Release 2000, 68, 351-359.

7. Sah, H. Protein behavior at the water/methylene chloride interface. J. Pharm. Sci. 1999, 88, 1320- 1325.

8. Xing, D.K.L.; Cranet, D.T.; Bolgiano, B.; Corbel, M.J.; Jones, C.; Sesardic, D. Physico-chemical and immunological studies on the stability of free and microsphere-encapsulated tetanus toxoid in vitro. Vaccine 1996, 14, 1205-1213.

9. Johansen, P.; Men, Y.; Audran, R.; Corradin, G.; Merkle, H.P.; Gander, B. Improving stability and release kinetics of microencapsulated tetanus toxoid by co-encapsulation of additives. Pharm. Res. 1998, 15, 1103-1110.

10. Audran, R.; Men, Y.; Johansen, P.; Gander, B.; Corradin, G. Enhanced immunogenicity of microencapsulated tetanus toxoid with stabilizing agents. Pharm. Res. 1998, 15, 1111-1116.

11. Lu, W.; Park, T.G. Protein release from poly(lactic-co-glycolic acid) microspheres: Protein stability problems, PDA. J. Pharm. Sci. Technol. 1995, 49, 13-19.

12. Pérez, C.; Griebenow, K. Improoved activity and stability of lysozyme at the water $/ \mathrm{CH}_{2} \mathrm{Cl}_{2}$ interface: enzyme unfolding and aggregation and its prevention by polyols. J. Pharm. Pharmacol. 2001, 53, 1217-1226.

13. Cleland, J.L.; Jones, A.J.S. Stable formulations of recombinant human growth hormone and interferon-gamma for microencapsulation for encapsulation in bidegradable microspheres. Pharm. Res. 1996, 13, 1464-1474.

14. Singh, M.; Shirley, B.; Bajwa, K.; Samara, E.; Hora, M.; O’Hagan, D. Controlled release of recombinant insulin-like growth factor from a novel formulation of polylactide-co-glycolide microparticles. J. Control. Release 2001, 70, 21-28.

15. Carrasquillo, K.; Stanley, A.M.; Aponte-Carro, J.C.; Jésus, P.; Costantino, H.R.; Bosques, C.J.; Griebenow, K. Non-aqueous encapsulation of excipient-stabilized spray-freeze dried BSA into poly(lactide-co-glycolide) microspheres results in release of native protein. J. Control. Release 2001, 76, 199-208.

16. Tobío, M.; Schwendeman, S.P.; Guo, Y.; McIver, J.; Langer, R.; Alonso, M.J. Improved immunogenicity of a core-coated tetanus toxoid delivery system. Vaccine 2000, 18, 618-622.

17. Blanco, D.; Alonso, M.J. Protein encapsulation and release from poly(lactide-co-glycolide) microspheres: Effect of the protein and polymer properties and of the co-encapsulation of surfactants. Eur. J. Pharm. Biopharm. 1998, 45, 285-294.

18. Schwendeman, S.P.; Tobío, M.; Joworowicz, M.; Alonso, M.J.; Langer, R. New strategies for the microencapsulation of tetanus vaccine. J. Microencap. 1998, 15, 299-318.

19. Nihant, N.; Schugens, C.H.; Granfils, C.H.; Jerôme, R.; Teyssié, P.H. Polylactide microparticles prepared by double emulsion-evaporation. II. Effect of the poly(lactide-co-glycolide) composition on the stability of the primary and secondary emulsions. J. Colloid Interface Sci. 1995, 173, $55-65$.

20. Nihant, N.; Schugens, C.H.; Granfils, C.H.; Jerôme, R.; Teyssié, P.H. Polylactide microparticles prepared by double emulsion/evaporation technique. I. Effect of primary emulsion stability. Pharm. Res. 1994, 11, 1479-1484. 
21. Crotts, G.; Park, T.G. Stability and release of bovine serum albumin encapsulated within poly(D,L- lactide-co-glycolide) microparticles. J. Control. Release 1997, 44, 123-124.

22. Castellanos, I.J.; Al-Azzam, W.; Griebenow, K. Effect of the covalent modification with poly(ethylene glycol) on a- chymotrypsin stability upon encapsulation in poly(lactic-co-glycolic) microspheres. J. Pharm. Sci. 2005, 94, 327-340.

23. Campana, R.A.; Namur, J.A.M.; Takata, C.S.; Araujo, P.S.; Bueno da Costa, M.H. Ionic interfaces and diphteria toxoid interactions. Prot. Expres. Purif. 2004, 33, 161-165.

24. Woody, R.W.; Dunker, K. Aromatic and cystine sidechain circular dichroism in proteins. In Circular Dichroism and the Conformational Analysis of Biomolecules, 1st ed.; Gerald D. Fasman, Plenum Press: New York, NY, USA, 1996; pp. 109-113.

25. Tilstra, L.; Mattice, W.L. The beta sheet to coil transition of polypeptides, as determined by circular dichroism. In Circular Dichroism and the Conformational Analysis of Biomolecules, 1st ed.; Fasman, G.D., Ed.; Plenum Press: New York, NY, USA, 1996; pp. 261-269.

26. Pérez, C.; Griebenow, K. Effects of salts on lysozyme stability at the water-oil interface and upon encapsulation in poly(lactic-co-glycolic) acid microspheres. Biotechnol. Bioeng. 2002, 82, 825-832.

27. Curtis, R.A.; Ulrich, J.; Montaser, A.; Prausnitz, J.M.; Blanch, H.W. Protein-protein interactions in concentrated electrolyte solutions. Biotechnol. Bioeng. 2002, 79, 367-380.

28. Dér, A.; Kelemen, L.; Fábián, L.; Taneva, S.G.; Fodor, E.; Pálli, T.; Cupane, A.; Cacace, M.G.; Ramsden, J.J. Interfacial water structure controls protein conformation, J. Phys. Chem. B. 2007, 111, 5344-5350.

29. Zhang, Y.; Cremer, P.S. Interactions between macromolecules and ions: The Hoffmeister series. Curr. Opin. Chem. Biol. 2006, 10, 658-663.

30. Zhou, H.X. Interactions of macromolecules with salt ions: an electrostatic theory for the Hoffmeister effect. Proteins 2005, 61, 69-78.

31. Boström, M.; Williams, D.R.M.; Niham, B.W. Specific ion effects: why the properties of lysozyme in salt solutions follow a Hoffmeister series. Biophysical J. 2003, 85, 686-694.

32. Leberman, R. The Hoffmeister series and ionic strength. FEBS 1991, 284, 193- 294.

33. Biresaw, G.; McKenzie, D.C.; Bunton, C.A.; Nicoli, D.F. Dynamic light scattering study of a micellar system of low fractional ionization: $(\mathrm{CTA})_{2} \mathrm{SO}_{4}+\mathrm{Na}_{2} \mathrm{SO}_{4}$. J. Phys. Chem. 1985, 89, 5144-5146.

(C) 2009 by the authors; licensee Molecular Diversity Preservation International, Basel, Switzerland. This article is an open-access article distributed under the terms and conditions of the Creative Commons Attribution license (http://creativecommons.org/licenses/by/3.0/). 